\title{
Effect of Dietary sugar beet pulp supplementation on growth performance, nutrient digestibility, fecal Microflora, blood profiles and Diarrhea incidence in weaning pigs
}

C. L. Yan' ${ }^{1}$, H. S. Kim ${ }^{1}$, J. S. Hong ${ }^{1}$, J. H. Lee' ${ }^{1}$, Y. G. Han' ${ }^{1}$, Y. H. Jin², S. W. Son ${ }^{3}$, S. H. Ha ${ }^{3}$ and Y. Y. Kim ${ }^{1,4^{*}}$

\begin{abstract}
Background: In 2006, the European Union (EU) has decided to forbid use of antibiotics as growth promoters. Although many researches had been conducted about fiber source as alternatives of antibiotics, there are still lack of reports in the literature about the optimum level of sugar beet pulp supplementation, affecting growth performance and nutrient digestibility in weaning pigs. Therefore, different level of sugar beet pulp was added to diets to determine the effects of sugar beet pulp supplementation on growth performance, nutrient digestibility, fecal microflora, blood profile and incidence of diarrhea in weaning pigs.

Methods: A total of 200 weaning pigs [(Yorkshire $\times$ Landrace) $\times$ Duroc], averaging $9.01 \pm 1.389 \mathrm{~kg}$ of initial body weight were, allotted to 5 treatments in a randomized complete block (RCB) design. Each treatment was composed of 4 replicates with 10 pigs per pen. The treatments were control treatment: Corn-SBM basal diet + ZnO (phase 1: 0.05\%; phase 2; 0.03\%) and four different levels of sugar beet pulp were supplemented in Corn-SBM basal diet (3, 6, 9 or 12\%). Two phase feeding programs (phase 1: 1-2 weeks; phase 2: 3-5 weeks) were used for 5 week of growth trial.

Results: In feeding trial, there were no significant differences in growth performance and incidence of diarrhea among treatments. The E.coli counts were not significantly different among dietary treatments but linear response was observed in Lactobacillus counts as sugar beet pulp supplementation increased $(P<0.05)$. In addition, IGF-1, IgA and IgG were not affected by dietary treatments. However, the BUN concentration was decreased when pigs were fed the treatments of diets with SBP compared to that of control treatment $(P<0.05)$. In nutrient digestibility, crude fiber and NDF digestibilities were improved as the sugar beet pulp increased $(P<0.05)$. However, digestibilities of crude ash, crude fat, crude fiber and nitrogen retention were not affected by dietary sugar beet pulp levels.
\end{abstract}

Conclusion: This experiment demonstrated that sugar beet pulp can be supplemented in weaning pigs' diet instead of $\mathrm{ZnO}$ to prevent postweaning diarrhea without any detrimental effect on growth performance.

Keywords: Sugar beet pulp, Weaning pig, Growth performance, Blood profiles, Nutrient digestibility

\footnotetext{
* Correspondence: yooykim@snu.ac.kr

${ }^{1}$ Department of Agricultural Biotechnology, College of Animal Life Sciences,

Seoul National University, 1 Gwanak-ro, Gwanak-gu, Seoul 08826, Republic of

Korea

${ }^{4}$ College of Agriculture and Life Sciences, Seoul National University, Seoul

08826, South Korea

Full list of author information is available at the end of the article
} 


\section{Background}

Antibiotics have been used in livestock feeding to increase growth performance and to prevent disease. However, in 2006, the European Union (EU) has decided to forbid use of antibiotics as growth promoters [1]. Also, in Korea, using antibiotics as growth promoters have been banned from 2011. The ban on antibiotics has been reported as the cause of increasing diarrhea followed by impaired growth performance and high mortality of weaning pigs [2].

Feeding a minimum level of fiber can support normal physiological activity in the digestive tract [3]. Diets or ingredients which have high fiber content in young pigs may affect as negatively to voluntary feed intake and nutrient digestibility, respectively [4]. Recent research, it has shown that dietary fiber supplementation can reduce the incidence of diarrhea and improve performance in weaning pigs $[5,6]$. Dietary fiber includes soluble dietary fiber (SDF) and insoluble dietary fiber (IDF). Due to supplemented SDF to weaning pigs, it gives the positive effect to decrease the incidence of diarrhea and improve to gut health. Because of high water holding capacity, SDF could affect to those facts [7]. In addition, the bacteria from small and large intestine could affect to degrade the most of SDF and partial of IDF [7-9]. When SDF arrived into the large intestine, the degree of fermentation is faster and better than IDF $[10,11]$. In the large intestine, number and activity of microbes are increased by SDF and it also work in the ileum as well [3].

Sugar beet pulp (SBP) includes high level of soluble fiber such as pectins and glucans [12]. However, there are still lack of reports in the literature about the optimum level of sugar beet pulp supplementation, affecting growth performance and nutrient digestibility in weaning pigs. Therefore, present study was conducted to determine the effects of sugar beet pulp supplementation on growth performance, nutrient digestibility, fecal microflora, blood profile and incidence of diarrhea in weaning pigs.

\section{Methods}

\section{Animal and management}

All experimental procedures involving animals were conducted in accordance with the Animal Experimental Guidelines provided by the Seoul National University Institutional Animal Care and Use Committee (SNUIACUC; SNU-160613-10).

A total of 200 weaning pigs [(Yorkshire $\times$ Landrace) $\times$ Duroc] with an average body weight of $9.01 \pm 1.389 \mathrm{~kg}$, weaned at $25 \pm 3$ days. The weaning house temperature was maintained at $31{ }^{\circ} \mathrm{C}$, and then gradually fallen to $26^{\circ} \mathrm{C}$ at the end of the experiment.
During the 5 weeks feeding trial, weaning pigs were allowed ad libitum access to water and diets.

\section{Experimental design and diet}

Experimental pigs were grouped into a randomized complete block (RCB) design in 4 replicates with 10 pigs per pen. Treatments consisted of 4 different levels of sugar beet pulp $(3.0,6.0,9.0,12.0 \%)$ and one positive control (PC) treatment. Present study was conducted with corn-SBM-barley based diet and two-phase feeding program was used. Phase 1 diet contained $20.56 \%$ crude protein and $1.35 \%$ lysine for $0-2$ weeks. Phase 2 diet contained $18.88 \%$ crude protein and $1.15 \%$ lysine for 3-5 weeks. All other nutrients of experimental diets were met or slightly exceeded the nutrient requirements [13]. Formulas and composition of the experimental diets were shown in Tables 1 and 2.

\section{Growth performance}

Body weight and feed consumption were recorded at 0,2 , and 5 weeks to calculate average daily gain (ADG), average daily feed intake (ADFI) and gain to feed ratio ( $\mathrm{G}: \mathrm{F}$ ratio).

\section{Blood profiles}

Blood samples were taken from the jugular vein of randomly selected five pigs in each treatment for measuring blood urea nitrogen (BUN), insulin growth like factor-1(IGF-1), immunoglobulin A (IgA) and G (IgG) after pigs were fasten $3 \mathrm{~h}$. Collected blood samples were centrifuged for $15 \mathrm{~min}$ at $3000 \mathrm{rpm}$ on $4{ }^{\circ} \mathrm{C}$ (Eppendorf centrifuge 5810R, Germany). Be carefully remove the serums to plastic vials and stored at $-20{ }^{\circ} \mathrm{C}$. The concentration of BUN and IGF-1 were analyzed using blood analyzer (Ciba-Corning model, Express plus, Ciba Corning Diagnostics Co.) and IgA, IgG were analyzed by ELISA assay (ELISA Starter Accessory Package, Pig IgA and IgG ELISA Quantitation Kit; Bethyl).

\section{Digestibility trial}

According to a completely randomized design (CRD), fifteen weaning pigs $(14.42 \pm 0.45 \mathrm{~kg})$ were allotted to 5 treatment with 3 replicates. During the digestibility trial, diet was provided twice per day at 7:00 and 19:00 h by three times the maintenance energy requirement (106 kcal of $\mathrm{ME} / \mathrm{kg}$ of $\mathrm{BW}^{0.75}$ ) and water was provided ad libitum [14]. After 7 days of adaptation period, fecal and urine samples were collected 5 days. To determine the first and last day of collection days, $0.5 \%$ of ferric oxide and chromium oxide were added in the first and last experimental diet as selection marker, respectively. Fecal and urine were collected daily and stored $-20{ }^{\circ} \mathrm{C}$ then fecal samples were dried in air-forced drying oven at $60{ }^{\circ} \mathrm{C}$ for $72 \mathrm{~h}$, and ground into $1 \mathrm{~mm}$ particles in a 
Table 1 Formula and chemical composition of diets (phase 1)

\begin{tabular}{|c|c|c|c|c|c|}
\hline \multirow[t]{2}{*}{ Ingredients,\% } & \multicolumn{5}{|c|}{ Treatment $^{\mathrm{a}}$} \\
\hline & Con & SBP3 & SBP6 & SBP9 & SBP12 \\
\hline Corn & 25.01 & 21.61 & 17.63 & 13.37 & 9.63 \\
\hline Soy bean meal & 33.16 & 33.05 & 32.88 & 32.67 & 32.51 \\
\hline Wheat & 9.70 & 9.88 & 10.60 & 11.65 & 12.12 \\
\hline Barley & 15.00 & 15.00 & 15.00 & 15.00 & 15.00 \\
\hline Whey powder & 4.00 & 4.00 & 4.00 & 4.00 & 4.00 \\
\hline Lactose & 8.00 & 8.00 & 8.00 & 8.00 & 8.00 \\
\hline Sugar Beet Pulp & 0.00 & 3.00 & 6.00 & 9.00 & 12.00 \\
\hline Soy-oil & 1.73 & 2.15 & 2.62 & 3.09 & 3.55 \\
\hline MDCP & 1.36 & 1.40 & 1.42 & 1.45 & 1.48 \\
\hline Limestone & 1.03 & 0.95 & 0.89 & 0.81 & 0.74 \\
\hline L-Lysine-HCl, 78\% & 0.29 & 0.29 & 0.29 & 0.29 & 0.29 \\
\hline DL-methionine, 80\% & 0.08 & 0.08 & 0.08 & 0.08 & 0.09 \\
\hline L-threonine, 99\% & 0.09 & 0.09 & 0.09 & 0.09 & 0.09 \\
\hline Vit. Mix ${ }^{\mathrm{b}}$ & 0.10 & 0.10 & 0.10 & 0.10 & 0.10 \\
\hline Min. Mix & 0.10 & 0.10 & 0.10 & 0.10 & 0.10 \\
\hline Salt & 0.30 & 0.30 & 0.30 & 0.30 & 0.30 \\
\hline Zinc oxide & 0.05 & 0.00 & 0.00 & 0.00 & 0.00 \\
\hline Total & 100.00 & 100.00 & 100.00 & 100.00 & 100.00 \\
\hline \multicolumn{6}{|l|}{ Chemical composition } \\
\hline $\mathrm{ME}^{\mathrm{d}}, \mathrm{kcal} / \mathrm{kg}$ & 3265.04 & 3265.01 & 3265.01 & 3265.00 & 3265.01 \\
\hline Total lysine $e^{d}, \%$ & 1.35 & 1.35 & 1.35 & 1.35 & 1.35 \\
\hline Total methionine ${ }^{d}, \%$ & 0.35 & 0.35 & 0.35 & 0.35 & 0.35 \\
\hline Total threonine ${ }^{d}, \%$ & 0.86 & 0.86 & 0.86 & 0.86 & 0.86 \\
\hline Calcium ${ }^{\mathrm{d}}, \%$ & 0.80 & 0.80 & 0.80 & 0.80 & 0.80 \\
\hline Total phosphorus ${ }^{\mathrm{d}}, \%$ & 0.65 & 0.65 & 0.65 & 0.65 & 0.65 \\
\hline Moisture $^{\mathrm{e}}, \%$ & 9.67 & 9.66 & 9.01 & 8.66 & 8.36 \\
\hline Crude Protein ${ }^{e}, \%$ & 20.71 & 20.64 & 20.69 & 20.80 & 20.62 \\
\hline Crude Ashe, \% & 6.35 & 6.36 & 6.50 & 6.42 & 6.09 \\
\hline Ether extract ${ }^{\mathrm{e}}, \%$ & 3.20 & 3.99 & 4.59 & 4.74 & 5.74 \\
\hline Crude fiber ${ }^{\mathrm{e}}, \%$ & 3.23 & 3.79 & 4.29 & 5.04 & 5.65 \\
\hline $\mathrm{NDF}^{\mathrm{e}}, \%$ & 13.38 & 11.55 & 13.13 & 14.22 & 17.03 \\
\hline $\mathrm{ADF}^{\mathrm{e}}, \%$ & 4.27 & 4.26 & 5.02 & 6.00 & 6.50 \\
\hline
\end{tabular}

${ }^{a}$ PC: corn-SBM based diet + ZnO 0.5\%, SBP3: basal diet + SBP 3\%, SBP6: basal diet + SBP 6\%, SBP9: basal diet + SBP 9\%, SBP12: basal diet + SBP 12\%

${ }^{b}$ Provided the following quantities of vitamins per $\mathrm{kg}$ of complete diet: Vit $\mathrm{A}$ 8000 IU; Vit $D_{3}, 1800$ IU; Vit. E, 80 IU; Vit. $K_{3}, 2$ mg; Rivoflavin, 7 mg; Calcium

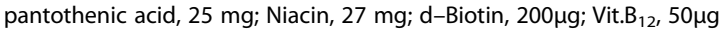

' Provided the following quantities of minerals per $\mathrm{kg}$ of complete diet: $\mathrm{Fe}$,

150 mg; Cu, 105 mg; Mn, 51 mg; l, 1 mg; Se, 0.3 mg; Zn, 72 mg

d Calculated value

e Analyzed value

Wiley mill for chemical analysis included moisture, protein, fat and ash contents [15]. Total urine was collected daily in a plastic container containing $50 \mathrm{ml}$ of $4 \mathrm{~N} \mathrm{H}_{2} \mathrm{SO}_{4}$ to avoid nitrogen evaporation and frozen during the 5 days of collection period for nitrogen retention analysis.
Table 2 Formula and chemical composition of diets (phase 2)

\begin{tabular}{|c|c|c|c|c|c|}
\hline \multirow[t]{2}{*}{ Ingredients, $\%$} & \multicolumn{5}{|c|}{ Treatment $^{\mathrm{a}}$} \\
\hline & Con & SBP3 & SBP6 & SBP9 & SBP12 \\
\hline Corn & 35.34 & 31.93 & 28.44 & 24.83 & 20.98 \\
\hline Soy bean meal & 28.68 & 28.55 & 28.43 & 28.31 & 28.16 \\
\hline Wheat & 10.40 & 10.57 & 10.78 & 11.09 & 11.68 \\
\hline Barley & 15.00 & 15.00 & 15.00 & 15.00 & 15.00 \\
\hline Whey powder & 2.00 & 2.00 & 2.00 & 2.00 & 2.00 \\
\hline Lactose & 4.00 & 4.00 & 4.00 & 4.00 & 4.00 \\
\hline Sugar Beet Pulp & 0.00 & 3.00 & 6.00 & 9.00 & 12.00 \\
\hline Soy-oil & 1.73 & 2.16 & 2.61 & 3.07 & 3.53 \\
\hline MDCP & 1.16 & 1.19 & 1.22 & 1.25 & 1.28 \\
\hline Limestone & 0.91 & 0.84 & 0.76 & 0.69 & 0.61 \\
\hline L-Lysine-HCl, 78\% & 0.19 & 0.19 & 0.19 & 0.19 & 0.19 \\
\hline DL-methionine, 80\% & 0.04 & 0.05 & 0.05 & 0.05 & 0.05 \\
\hline L-threonine, 99\% & 0.02 & 0.02 & 0.02 & 0.02 & 0.02 \\
\hline Vit. Mix ${ }^{\mathrm{b}}$ & 0.10 & 0.10 & 0.10 & 0.10 & 0.10 \\
\hline Min. Mix ${ }^{c}$ & 0.10 & 0.10 & 0.10 & 0.10 & 0.10 \\
\hline Salt & 0.30 & 0.30 & 0.30 & 0.30 & 0.30 \\
\hline Zinc oxide & 0.03 & 0.00 & 0.00 & 0.00 & 0.00 \\
\hline Total & 100.00 & 100.00 & 100.00 & 100.00 & 100.00 \\
\hline
\end{tabular}

Chemical composition

$\mathrm{ME}^{\mathrm{d}}, \mathrm{kcal} / \mathrm{kg}$

$\begin{array}{lllll}3265.01 & 3265.01 & 3265.00 & 3265.01 & 3265.02\end{array}$

Total lysine ${ }^{d}, \%$

$\begin{array}{lllll}1.15 & 1.15 & 1.15 & 1.15 & 1.15\end{array}$

Total methionine ${ }^{\mathrm{d}}, \%$

$0.31 \quad 0.31$

0.31

0.31

0.31

Total threonine ${ }^{\mathrm{d}}, \%$

$0.74 \quad 0.74$

0.74

0.74

0.74

Calcium ${ }^{\mathrm{d}}$ \%

$0.70 \quad 0.70$

0.70

0.70

0.70

Total phosphorus ${ }^{\mathrm{d}}, \%$

0.65

0.65

0.65

0.65

0.65

Moisture ${ }^{e} \%$

$9.50 \quad 9.02$

8.99

8.76

8.82

Crude Protein ${ }^{\mathrm{e}} \%$

19.23

19.22

18.78

18.86

19.04

Crude Ashe,\%

$6.05 \quad 6.09$

6.26

5.92

6.14

Ether extract ${ }^{\mathrm{e}}$,\%

$3.77 \quad 4.33$

4.66

4.92

5.46

Crude fiber ${ }^{\mathrm{e}}$, $\%$

$3.54 \quad 4.45$

4.92

6.15

6.56

$\mathrm{NDF}^{\mathrm{e}}, \%$

$13.29 \quad 13.96$

15.15

$17.70 \quad 18.85$

$\mathrm{ADF}^{\mathrm{e}}, \%$

$4.14 \quad 4.68$

5.25

6.54

6.98

a PC: corn-SBM based diet + ZnO 0.3\%, SBP3: basal diet + SBP 3\%, SBP6: basal diet + SBP 6\%, SBP9: basal diet + SBP 9\%, SBP12: basal diet + SBP 12\%

${ }^{b}$ Provided the following quantities of vitamins per kg of complete diet: Vit $A$, 8000 IU; Vit $D_{3}, 1800$ IU; Vit. E, 80 IU; Vit. K 2,2 mg; Rivoflavin, 7 mg; Calcium pantothenic acid, 25 mg; Niacin, 27 mg; d-Biotin, 200 $\mu$; Vit. $B_{12}, 50 \mu \mathrm{g}$

c Provided the following quantities of minerals per $\mathrm{kg}$ of complete diet: Fe,

150 mg; Cu, 105 mg; Mn, 51 mg; l, 1 mg; Se, 0.3 mg; Zn, 72 mg

d Calculated value

e Analyzed value

\section{Diarrhea incidence}

During the whole feeding trial period, diarrhea score was recorded once a day (10:00) by counting the number of pigs with diarrhea per pen. The diarrhea score was from 0 (no pigs with diarrhea) to 10 (all pigs with diarrhea). 


\section{Fecal microflora}

Fecal E.coil and Lactobacillus count were measured at 0, 2 and 5 weeks. Samples were collected $1 \mathrm{~g}$ of feces and diluted with $9 \mathrm{ml}$ of distilled water. After mixing the solution, it was taken $1 \mathrm{~g}$ and diluted with $9 \mathrm{ml}$ of distilled water again. Like this way of dilution, samples was diluted to $1 / 10^{5}$ concentration of initial diluted solution. Each diluted solution was smeared in petridish having MacConkey agar (BBL ${ }^{\mathrm{Tm}}, \mathrm{BD}$, USA) and Lactobacilli MRS (Difco $\left.^{\text {тм }}, \mathrm{BD}, \mathrm{USA}\right)$ Broth respectively. There agar plates were incubated at $37^{\circ} \mathrm{C}$ for $24 \mathrm{~h}$ for E.coil and Lactobacillus proliferation. After incubation, the number of fecal E.coil and Lactobacillus were counted.

\section{Chemical and statistical analysis}

Experimental diet and excreta were analyzed for contents of dry matter (procedure 967.03 [15]); ash (procedure 923.03 [15]). The nitrogen content of feces and urine was analyzed by using the Kjeldahl procedure with Kjeltec (KjeltecTM 2200, Foss Tecator, Sweden) and calculating the CP content (Nitrogen $\times 6.25$; procedure 981.10 [15]). Experimental data were analyzed as a randomized complete block (RCB) design using the General Linear Model (GLM) procedure of SAS. In the growth performance data, a pen was considered an experimental unit, while an individual pig was used as the data unit for data on nutrient digestibility, fecal microflora, blood profile, and incidence of diarrhea. The effects of the levels of sugar beet pulp were analyzed while linear and quadratic components were analyzed by orthogonal polynomial contrasts. Differences were determined significant at $P<0.05$.

\section{Results and discussion Growth performance}

The result of body weight (BW), average daily gain (ADG), average daily feed intake (ADFI) and feed efficiency (G:F ratio) are presented in Table 3. During experimental period, there were no significant differences in BW, ADG, ADFI, G:F ratio. Variable results were showed in the literature with the effect of dietary fiber on growth performance in weaning pigs. Most results reported negative effect of fiber inclusion on growth performance of piglet $[16,17]$. In contrast, Longland et al. [18] reported no difference in growth performance of pig weaned at 21 days of age that fed diet with 15\% sugar beet pulp. And Gill et al. [19] reported no adverse effects on ADG when fed a cereal-based diet containing 0, 15 and 18.5\% of sugar beet pulp to 4-8 week old piglets. In other experiment with $6 \%$ sugar beet pulp in a wheat based diet, a positive effect on growth performance was observed after weaning pigs [20]. The growth performance in current study showed no negative effect when weaning pigs were fed diet with sugar beet pulp. The result appeared to conflict
Table 3 Effects of sugar beet pulp levels supplementation on growth performance in weaning pigs ${ }^{a}$

\begin{tabular}{|c|c|c|c|c|c|c|c|c|}
\hline \multirow[t]{2}{*}{ Criteria } & \multicolumn{5}{|c|}{ Treatment $^{b}$} & \multirow[t]{2}{*}{ SEM $^{C}$} & \multicolumn{2}{|c|}{$P$-value ${ }^{d}$} \\
\hline & PC & SBP3 & SBP6 & SBP9 & SBP12 & & Lin. & Quad. \\
\hline \multicolumn{9}{|c|}{ Body weight, kg } \\
\hline Initial & 9.01 & 9.01 & 9.01 & 9.01 & 9.01 & 0.300 & - & - \\
\hline 2 week & 12.83 & 12.15 & 12.48 & 12.63 & 12.32 & 0.380 & 0.68 & 0.86 \\
\hline 5 week & 20.79 & 19.77 & 21.21 & 22.67 & 21.23 & 0.625 & 0.16 & 0.47 \\
\hline \multicolumn{9}{|l|}{ ADG, $g$} \\
\hline 0-2 week & 273 & 229 & 248 & 259 & 235 & 11.7 & 0.80 & 0.83 \\
\hline 3-5 week & 379 & 370 & 393 & 478 & 424 & 18.9 & 0.20 & 0.29 \\
\hline 0-5 week & 337 & 314 & 336 & 390 & 349 & 14.8 & 0.28 & 0.37 \\
\hline \multicolumn{9}{|l|}{ ADFI, g } \\
\hline 0-2 week & 352 & 308 & 345 & 332 & 293 & 10.2 & 0.45 & 0.73 \\
\hline 3-5 week & 821 & 761 & 857 & 853 & 747 & 22.1 & 0.83 & 0.99 \\
\hline 0-5 week & 634 & 577 & 653 & 645 & 566 & 16.3 & 0.76 & 0.93 \\
\hline \multicolumn{9}{|l|}{ G:F ratio } \\
\hline 0-2 week & 0.78 & 0.73 & 0.73 & 0.80 & 0.81 & 0.025 & 0.17 & 0.52 \\
\hline 3-5 week & 0.57 & 0.59 & 0.64 & 0.71 & 0.65 & 0.033 & 0.42 & 0.60 \\
\hline 0-5 week & 0.68 & 0.68 & 0.75 & 0.81 & 0.72 & 0.035 & 0.58 & 0.69 \\
\hline
\end{tabular}

${ }^{a} A$ total 200 weaning pigs was fed from average initial body $9.01 \pm 1.389 \mathrm{~kg}$

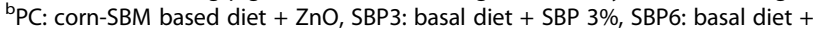
SBP 6\%, SBP9: basal diet + SBP 9\%, SBP12: basal diet + SBP $12 \%$ 'Standard error of means

dProbability values for the effects of SBP3, SBP6, SBP9, SBP12

the held belief that NSP (non-starch polysaccharide) was cannot be fermented and utilized by young pigs [21, 22].

\section{Diarrhea incidence}

The incidence of diarrhea was showed in Table 4 and there was no significant difference among treatments in whole experimental period. Sugar beet pulp had a high water holding capacity (WHC) and swelling water capacity (SWC), which increased volume of digest, viscosity and water retention [23, 24]. The results were similar to result of Berrocoso et al. [25]. With those observation, during 7 to $10 \mathrm{~d}$ postweaning period, pigs adjusted to solid feed consumption and it proved that proper amounts of soluble fiber improved the healthy fermentation of undigested nutrients. Because of gastrointestinal tract (GIT) microflora, it helped to ferment soluble fiber sources and the environment of GIT was also improved and stabled, besides the incidence of diarrhea also was reduced [26]. In addition, weaning pigs 33 to $39 \mathrm{~d}$ old with $12 \%$ sugar beet pulp in their diet made improved digestive functions and this was better result than other weaning pigs fed control diet [20].

\section{Fecal micorflora}

The effects of sugar beet pulp supplementation on fecal microflora were showed in Table 5 . There were linear 
Table 4 Effects of sugar beet pulp levels supplementation on incidence of diarrhea in weaning pigs

\begin{tabular}{|c|c|c|c|c|c|c|c|c|}
\hline \multirow[t]{2}{*}{ Criteria } & \multicolumn{5}{|c|}{ Treatment $^{a}$} & \multirow[t]{2}{*}{$\mathrm{SEM}^{\mathrm{b}}$} & \multicolumn{2}{|c|}{$P$-value ${ }^{c}$} \\
\hline & $P C$ & SBP3 & SBP6 & SBP9 & SBP12 & & Lin. & Quad. \\
\hline \multicolumn{9}{|c|}{ Diarrhea score ${ }^{d}$} \\
\hline 0-2 week & 1.71 & 1.57 & 1.36 & 1.43 & 1.43 & 0.125 & 0.77 & 0.70 \\
\hline 3-5 week & 1.14 & 0.95 & 0.81 & 0.71 & 0.76 & 0.075 & 0.33 & 0.53 \\
\hline 0-5 week & 1.37 & 1.20 & 1.03 & 1.00 & 1.03 & 0.071 & 0.42 & 0.51 \\
\hline
\end{tabular}

a PC: corn-SBM based diet + ZnO, SBP3: basal diet + SBP 3\%, SBP6: basal diet + SBP 6\%, SBP9: basal diet + SBP 9\%, SBP12: basal diet + SBP 12\%

${ }^{b}$ Standard error of means

C 0 (No pigs with diarrhea) - 10 (All pigs with diarrhea)

d Probability values for the effects of SBP3, SBP6, SBP9, SBP12

response on Lactobacillus counts as the level of sugar beet pulp increased in whole experimental period (linear, $P<0.05)$. In contrary, in whole experimental period, $E$. coli counts had no significant differences among treatments. Recently, some authors found that the decrease in the enteric $E$. coli after weaning was smaller when fed diet with $\mathrm{ZnO}$ [27]. So present study showed that $E$. coil was on the decrease in weaning pigs within PC treatment and treatments of diet with sugar beet pulp, together. These results were the same with previous researches [11, 28, 29]. Prohaska [30] and May et al. [31] reported that fermentation of dietary fiber produced short chain fatty acids (SCFA), which decreased the gut content $\mathrm{pH}$. In an acidic environment, the growth of intestinal bacterial pathogens was restrained by SCFA. Edwards [32] found that feeding diet with dietary fiber on weaning pigs increased intestinal counts of Lactobacillus and reduced the incidence of diarrhea. Soluble dietary fiber increased the number and activity of microbes by soluble dietary fiber in the large intestine,

Table 5 Effects of sugar beet pulp levels supplementation on fecal microflora in weaning pigs ${ }^{a}$

\begin{tabular}{|c|c|c|c|c|c|c|c|c|}
\hline \multirow[t]{2}{*}{ Criteria } & \multicolumn{5}{|c|}{ Treatment $^{\mathrm{b}}$} & \multirow[t]{2}{*}{ SEM $^{c}$} & \multicolumn{2}{|c|}{$P$-value ${ }^{d}$} \\
\hline & $P C$ & SBP3 & SBP6 & SBP9 & SBP12 & & Lin. & Quad. \\
\hline \multicolumn{9}{|c|}{ E. coli, cfu/ml } \\
\hline Initial & 5.84 & 5.84 & 5.84 & 5.84 & 5.84 & 0.109 & - & - \\
\hline 2 week & 3.87 & 4.44 & 4.22 & 4.21 & 4.87 & 0.131 & 0.30 & 0.12 \\
\hline 5 week & 4.41 & 4.00 & 4.17 & 5.50 & 4.33 & 0.214 & 0.29 & 0.17 \\
\hline \multicolumn{9}{|c|}{ Lactobacillus, cfu/ml } \\
\hline Initial & 6.63 & 6.63 & 6.63 & 6.63 & 6.63 & 0.053 & - & - \\
\hline 2 week & 6.08 & 6.53 & 6.36 & 7.17 & 6.64 & 0.130 & 0.04 & 0.32 \\
\hline 5 week & 7.81 & 8.03 & 7.96 & 8.04 & 8.19 & 0.047 & 0.02 & 0.97 \\
\hline
\end{tabular}

${ }^{a}$ Least squares means for 4 pigs per treatment

b PC: corn-SBM based diet + ZnO, SBP3: basal diet + SBP 3\%, SBP6: basal diet

+ SBP 6\%, SBP9: basal diet + SBP 9\%, SBP12: basal diet + SBP $12 \%$

c Standard error of means

d Probability values for the effects of SBP3, SBP6, SBP9, SBP12 and even in the ileum [3]. And a reduction in $\mathrm{pH}$ accelerated growth of beneficial bacteria like Lactobacillus [33].

\section{Nutrient digestibility}

The effects of sugar beet pulp supplementation on nutrient digestibility and nitrogen retention were showed in Table 6. Crude fiber, neutral detergent fiber (NDF) and acid detergent fiber (ADF) digestibility were improved as dietary sugar beet pulp level increased $(P<0.05)$. There was linear response on NDF digestibility as sugar beet pulp level increased (linear, $P<0.05$ ) and crude ash, crude fat, crude fiber and ADF tended to improve linearly as sugar beet pulp level increased (linear, $P<0.10)$. However, nitrogen retention was not affected by the supplementation level of sugar beet pulp. The results showed that increasing level of sugar beet pulp played a positive effects in nutrient digestibility. It was the same as the some previous researches. Bindelle et al. [34] found that there was a linear increase in the digestibility when added 0, 10, 20 and 30\% levels of sugar beet pulp fed to growing pigs. In addition, Freire et al. [35] represented that increasing DM (dry matter) digestibility when 20\% sugar beet pulp was included in a cornfishmeal diet and Chabeauti et al. [36] reported that ATTD (apparent total tract digestibility) of GE (gross energy) was increased in growing pigs when fed $16 \%$ sugar beet pulp. Also, the diets with 2.5 or $5 \%$ sugar beet pulp to feed piglet improved ATTP of all nutrients except crude protein [25]. Varel et al. [37] reported celluloytic bacteria like Fibrovacter succinogenes and Ruminococcus flavefaciens inhabited pig's large intestine. This was the reason for high fiber utilization or supplementation high level of NSP diets. So there was a positive effect in nutrient digestibility when pigs fed diets with a reasonable level of sugar beet pulp.

\section{Blood profiles}

The blood urea nitrogen (BUN) and insulin like growth factor-1 (IGF-1) concentration were showed in Table 7. In 5 week, the treatments of diets with sugar beet pulp presented lower BUN concentration than PC treatment $(P<0.05)$. In whole experimental period, pigs fed diets with sugar beet pulp treatments showed the numerically higher IGF-1 concentration than PC treatment. In general, BUN was the indicator for determination of amino acid utilization by pigs and it was directly related to intake of protein and inversely to quality of protein $[38,39]$. Hahn et al. [39] found BUN values had negative correlation with ADG and G:F ratio. Therefore, the difference of BUN at 5 week could be explained by the results that the treatments which sugar beet pulp was added got numerically higher results than PC treatment in ADG or G:F ratio until 3-5 weeks and it might 
Table 6 Effects of sugar beet pulp levels supplementation on nutrient digestibility in weaning pigs ${ }^{1}$

\begin{tabular}{|c|c|c|c|c|c|c|c|c|}
\hline \multirow[t]{2}{*}{ Criteria } & \multicolumn{5}{|c|}{ Treatment $^{2}$} & \multirow[t]{2}{*}{$\mathrm{SEM}^{3}$} & \multicolumn{2}{|c|}{$P$-value ${ }^{4}$} \\
\hline & $P C$ & SBP3 & SBP6 & SBP9 & SBP12 & & Lin. & Quad \\
\hline \multicolumn{9}{|c|}{ Nutrient digestibility,\% } \\
\hline Dry matter & 87.08 & 89.24 & 87.31 & 88.15 & 89.07 & 0.534 & 0.49 & 0.95 \\
\hline Crude protein & 85.13 & 87.55 & 86.06 & 85.10 & 86.25 & 0.553 & 0.96 & 0.69 \\
\hline Crude ash & 57.00 & 71.15 & 66.92 & 65.85 & 71.31 & 2.013 & 0.08 & 0.35 \\
\hline Crude fat & 76.09 & 84.05 & 79.31 & 81.34 & 86.40 & 1.425 & 0.07 & 0.93 \\
\hline Crude fiber & $55.07^{b}$ & $66.64^{\mathrm{ab}}$ & $62.92^{\mathrm{ab}}$ & $74.14^{\mathrm{a}}$ & $75.84^{\mathrm{a}}$ & 2.601 & 0.05 & 0.49 \\
\hline ADF & $44.89^{b}$ & $56.89^{\mathrm{ab}}$ & $53.92^{\mathrm{ab}}$ & $64.58^{\mathrm{a}}$ & $66.49^{a}$ & 2.741 & 0.07 & 0.58 \\
\hline NDF & $61.43^{c}$ & $68.64^{\mathrm{bc}}$ & $67.89^{b c}$ & $73.61^{\mathrm{ab}}$ & $76.77^{\mathrm{a}}$ & 1.681 & 0.02 & 0.40 \\
\hline \multicolumn{9}{|c|}{ Nitrogen retention, $\mathrm{g} / \mathrm{d}$} \\
\hline $\mathrm{N}$ intake & 20.16 & 20.27 & 19.92 & 19.66 & 20.18 & 0.059 & - & - \\
\hline Fecal N & 3.00 & 2.52 & 2.78 & 2.93 & 2.77 & 0.110 & 0.96 & 0.60 \\
\hline Urinary N & 5.74 & 4.39 & 7.13 & 4.50 & 4.21 & 0.394 & 0.21 & 0.24 \\
\hline $\mathrm{N}$ retention ${ }^{5}$ & 11.42 & 13.36 & 10.02 & 12.22 & 13.19 & 0.447 & 0.37 & 0.26 \\
\hline
\end{tabular}

${ }^{1} \mathrm{~A}$ total 15 weaning pigs was fed from average initial body $14.42 \pm 0.45 \mathrm{~kg}$

${ }^{2}$ PC: corn-SBM based diet + ZnO, SBP3: basal diet + SBP 3\%, SBP6: basal diet + SBP 6\%, SBP9: basal diet + SBP 9\%, SBP12: basal diet + SBP 12\%

${ }^{3}$ Standard error of means

${ }^{4}$ Probability values for the effects of SBP3, SBP6, SBP9, SBP12

${ }^{5} \mathrm{~N}$ retention $=\mathrm{N}$ intake - Fecal $\mathrm{N}$ - Urinary $\mathrm{N}$

$\mathrm{a}, \mathrm{b}, \mathrm{c}$ Means with different superscripts within the same row significantly differ $(P<0.05)$

improve gut health by increasing the level of sugar beet pulp supplementation.

IGF-1 was secreted when the growth hormones were stimulated and affected by nutritional status of animal. IGF-1 played an important role such as energy supply for cell growth, regulation of structure, function of cardiovaccular system and born growth [40]. In 5 weeks, pigs fed diets with sugar beet pulp showed numerically higher than PC treatment. Bhutta et al. [41] reported IGF-1 concentration was increased when someone took nutritional supplement. It could be thought of as improving intestine health by the addition of sugar beet pulp and

Table 7 Effects of sugar beet pulp levels supplementation on blood profiles in weaning pigs ${ }^{\text {a }}$

\begin{tabular}{|c|c|c|c|c|c|c|c|c|}
\hline \multirow[t]{2}{*}{ Criteria } & \multicolumn{5}{|c|}{ Treatment $^{b}$} & \multirow[t]{2}{*}{ SEM $^{c}$} & \multicolumn{2}{|c|}{$P$-value ${ }^{d}$} \\
\hline & $P C$ & SBP3 & SBP6 & SBP9 & SBP12 & & Lin. & Quad. \\
\hline \multicolumn{9}{|c|}{$\mid \mathrm{GF}-1, \mathrm{ng} / \mathrm{dl}$} \\
\hline Initial & 53.7 & 53.7 & 53.7 & 53.7 & 53.7 & 3.21 & - & - \\
\hline 2 week & 132.8 & 158.9 & 134.6 & 125.7 & 113.6 & 8.31 & 0.13 & 0.77 \\
\hline 5 week & 109.3 & 169.2 & 158.5 & 162.2 & 153.1 & 8.40 & 0.60 & 0.97 \\
\hline \multicolumn{9}{|l|}{ BUN, mg/dl } \\
\hline Initial & 6.96 & 6.96 & 6.96 & 6.96 & 6.96 & 0.306 & - & - \\
\hline 2 week & 10.70 & 11.06 & 10.58 & 11.60 & 9.48 & 0.423 & 0.44 & 0.45 \\
\hline 5 week & $12.16^{a}$ & $10.40^{\mathrm{b}}$ & $10.42^{b}$ & $9.90^{\mathrm{b}}$ & $10.08^{b}$ & 0.272 & 0.57 & 0.89 \\
\hline
\end{tabular}

a Least squares means for 5 pigs per treatment

b PC: corn-SBM based diet + ZnO, SBP3: basal diet + SBP 3\%, SBP6: basal diet

+ SBP 6\%, SBP9: basal diet + SBP 9\%, SBP12: basal diets + SBP 12\%

c Standard error of means

d Probability values for the effects of SBP3, SBP6, SBP9, SBP12 taking a nutritional supplement by fermentation of sugar beet pulp as dietary fiber.

\section{Immune response}

There was an intestinal microbiota in the GIT providing different benefits to the host and it stimulated the immune system $[42,43]$. And the immune system was impacted by VFA (volatile fatty acid) like butyrate [44]. However, the result of Table 8 showed no significant difference in $(\operatorname{Ig} A)$ and $(\operatorname{IgG})$ during the whole experimental period. So, the results demonstrated that

Table 8 Effects of sugar beet pulp levels supplementation on $\lg A$ and $\lg G$ in weaning pigs ${ }^{a}$

\begin{tabular}{|c|c|c|c|c|c|c|c|c|}
\hline \multirow[t]{2}{*}{ Criteria } & \multicolumn{5}{|c|}{ Treatment $^{\mathrm{b}}$} & \multirow[t]{2}{*}{ SEM $^{c}$} & \multicolumn{2}{|c|}{$P$-value ${ }^{d}$} \\
\hline & $P C$ & SBP3 & SBP6 & SBP9 & SBP12 & & Lin. & Quad. \\
\hline \multicolumn{9}{|c|}{$\operatorname{lgA}, \mathrm{mg} / \mathrm{ml}$} \\
\hline Initial & 0.12 & 0.12 & 0.12 & 0.12 & 0.12 & 0.009 & - & - \\
\hline 2 week & 0.22 & 0.20 & 0.19 & 0.39 & 0.29 & 0.028 & 0.10 & 0.46 \\
\hline 5 week & 0.46 & 0.52 & 0.45 & 0.50 & 0.45 & 0.029 & 0.68 & 0.93 \\
\hline \multicolumn{9}{|l|}{$\operatorname{lgG}, \mathrm{mg} / \mathrm{ml}$} \\
\hline Initial & 2.83 & 2.83 & 2.83 & 2.83 & 2.83 & 0.052 & - & - \\
\hline 2 week & 2.25 & 2.59 & 2.17 & 2.51 & 2.39 & 0.095 & 0.77 & 0.50 \\
\hline 5 week & 3.04 & 3.63 & 3.05 & 3.72 & 3.11 & 0.125 & 0.49 & 0.96 \\
\hline
\end{tabular}

${ }^{a}$ Least squares means for 5 pigs per treatment

b PC: corn-SBM based diet + ZnO, SBP3: basal diet + SBP 3\%, SBP6: basal diet

+ SBP 6\%, SBP9: basal diet + SBP 9\%, SBP12: basal diet + SBP 12\%

c Standard error of means

d Probability values for the effects of SBP3, SBP6, SBP9, SBP12 
supplementation of sugar beet pulp had no effects on IgA and IgG in weaning pigs.

\section{Implication}

In conclusion, sugar beet pulp as an alternative $\mathrm{ZnO}$ could be supplemented in weaning pigs. In growth performance, there was no significant difference among treatments during the experimental period. And pigs fed the treatments of diets with sugar beet pulp showed numerically lower than the treatment of diet with $\mathrm{ZnO}$ in incidence of diarrhea. Also, the increased level of sugar beet pulp supplementation, there was an increase in counts of Lactobacillus. There were positive effects in nutrient digestibility when pigs fed diets with sugar beet pulp and addition of sugar beet pulp could improve amino acid utilization and take nutritional supplement. And IgA could be increased by the increased level of sugar beet pulp supplementation. Consequently, sugar beet pulp as an alternative $\mathrm{ZnO}$ could be supplemented in weaning pigs without any detrimental effect on growth performance.

\section{Abbreviations}

ADF: Acid detergent fiber; ADFI: Average daily feed intake; ADG: Average daily gain; ATTD: Apparent total tract digestibility; BUN: Blood urea nitrogen; BW: Body weight; CP: Crude protein; CRD: Completely randomized design; DF: Dietary fiber; EU: European union; GE: Gross energy; GF: Ratio Gain to feed ratio; GIT: Gastrointestinal tract; IDF: Insoluble dietary fiber; IgA: Immunoglobulin A; IGF-1: Insulin growth like factor-1; IgG: Immunoglobulin G; ME: Metabolizable energy; NDF: Neutral detergent fiber; NSP: Non starch polysaccharide; PC: Positive control; RCBD: Randomized complete block design; SBM: Soy bean meal; SBP: Sugar beet pulp; SCFA: Short chain fatty acid; SDF: Soluble dietary fiber; SWC: Swelling water capacity; VFA: Volatile fatty acid; WHC: Water holding capacity; ZnO: Zinc oxide

\section{Acknowledgements}

\section{Funding}

This work was supported by Korea Institute of Planning and Evaluation for Technology in Food, Agriculture, Forestry and Fisheries(IPET) through Agri-Bio industry Technology Development Program, funded by Ministry of Agriculture, Food and Rural Affairs(MAFRA)(314022-3).

\section{Availability of data and materials}

Authors approved the data and materials availability.

\section{Authors' contributions}

YCL was mainly carried out this study and drafted the manuscript. KHS, HJS, $\llcorner H$, and HYG were participated in the feeding trial, digestibility trial and blood sampling, together. JYH performed the statistical analysis and discussed the results. SSW and HSH were were participated in the feeding trial and discussed the results. KYY conceived of the study, and participated in its design and coordination and helped to draft the manuscript. All authors read and approved the final manuscript.

\section{Ethics approval}

All experimental procedures involving animals were conducted in accordance with the Animal Experimental Guidelines provided by the Seoul National University Institutional Animal Care and Use Committee (SNU-IACUC; SNU-160613-10).

\section{Consent for publication}

Not applicable.

\section{Competing interests}

The authors declare that they have no competing interest.

\section{Publisher's note}

Springer Nature remains neutral with regard to jurisdictional claims in published maps and institutional affiliations.

\section{Author details}

${ }^{1}$ Department of Agricultural Biotechnology, College of Animal Life Sciences, Seoul National University, 1 Gwanak-ro, Gwanak-gu, Seoul 08826, Republic of Korea. ${ }^{2}$ Department of Agricultural College of Yanbian University, Yanji, Jilin 13300, China. ${ }^{3}$ PuKyung Pig Farmers Agricultural Cooperative, Gimhae 50925, Republic of Korea. ${ }^{4}$ College of Agriculture and Life Sciences, Seoul National University, Seoul 08826, South Korea.

Received: 9 January 2017 Accepted: 19 June 2017

Published online: 07 August 2017

\section{References}

1. Chen YJ, Kwon OS, Min BJ, Son KS, Cho JH, Hong JW. Effects of dietary Enterococcus faecium SF68 on growth performance, nutrient digestibility, blood characteristics and faecal noxious gas content in finishing pigs. AsianAust J Anim Sci. 2005:19:406-11.

2. Casewell M, Friis C, Marco E, McMullin P, Phillps I. The European ban on growth-promoting antibiotics and emerging consequences for human and animal health. J Antimicrob Chemother. 2003;52:159-61.

3. Wenk $C$. The role of dietary fibre in the digestive physiology of the pig. Anim Feed Sci Technol. 2001;90:21-33.

4. Kyriazakis I, Emmans GC. The voluntary feed intake of pigs given feeds based on wheat bran, dried citrus pulp and grass meal, in relation to measurements of bulk. Br J Nutr. 1995;73:191-207.

5. Mateos GG, Martin F, Latorre MA, Vicente B, Lazaro R. Inclusion of oat hulls in diets for young pigs based on cooked maize or cooked rice. Anim Sci. 2006;82:57-63.

6. Molist F, van Oostrum M, Pérez JF, Mateos GG, Nyachoti CM, van der Aar PJ. Relevance of functional properties of dietary fibre in diets for weanling pigs. Anim Feed Sci Technol. 2014;189:1-10.

7. Serena A, Jogensen H, Bach Knudsen KE. Digestion of carbohydrates and utilization of energy in sows fed diets with contrasting levels and physicochemical properties of dietary fiber. J Anim Sci. 2008;86:2208-16.

8. Urriola PE, Shurson GC, Stein HH. Digestibility of dietary fiber in distillers coproducts fed to growing pigs. J Anim Sci. 2010;88:2373-81.

9. Urriola $\mathrm{PE}$, Stein $\mathrm{HH}$. Comparative digestibility of energy and nutrients in fibrous feed ingredients fed to Meishan and Yorkshire pigs. J Anim Sci. 2012;90:802-12.

10. Nyman M, Asp NG, Cumming J, Wiggins H. Fermentation of dietary fibre in the intestinal tract: comparison between man and rat. Br J Nutr. 1986:55:487-96.

11. Bach Knudsen KE. Carbohydrates and lignin contents of plant materials used in animal feeding. Anim Feed Sci Technol. 1997;67:319-38.

12. Fadel JG, De Peters EJ, Arosemena A. Composition and digestibility of beet pulp with and without molasses and dried using three methods. Anim Feed Sci Technol. 2000;85:121-9.

13. NRC. Nutrient requirements of swine. 10th ed. Washington, DC: Natl. Acad. Press; 1998.

14. Kim BG, Lee JW, Stein HH. Energy concentration and phosphorus digestibility in whey powder, whey permeate, and low-ash whey permeate fed to weanling pigs. J Anim Sci. 2012;90:289-95.

15. AOAC. Official methods of analysis. 16th ed. Arlington, VA, USA: Association of Official Analytical Chemists; 1995.

16. Pluske JR, Durmic Z, Pethick DW, Mullan BP, Hampson DJ. Confirmation of the role of rapidly fermentable carbohydrates in the expression of swine dysentery in pigs after experimental infection. J Nutr. 1998;128:1737-44.

17. Pascoal LAF, Thomaz MC, Watanabe PH, Ruiz US, JMb E, Amorim AB, et al. Masson GCl. Fiber sources in diets for newly weaned piglets. R Bras Zootec. 2012:41:636-42

18. Longland AC, Carruthers J, Low AG. The ability of piglets 4 to 8 weeks old to digest and perform on diets containing two contrasting sources of nonstarch polysaccharides. Anim Prod. 1994;58:405-10.

19. Gill BP, Mellange J, Rooke JA. Growth performance and apparent nutrient digestibility in weaned piglets offered wheat-, barley- or sugar- 
beet pulp-based diets supplemented with food enzymes. J Anim Sci. 2000;70:107-18

20. Lizardo R, Peiniau J, Aumaitre A. Inclusion of sugar-beet pulp and change of protein source in the diet of the weaned piglet and their effects on digestive performance and enzymatic activities. Anim Feed Sci Technol. 1997:66:1-14.

21. Patience JF, Thacker PA, De Lange CFM. Swine nutrition guide. 2nd ed. Saskatchewan: Prairie Swine Centre Inc; 1989.

22. Beames RM. Seaweed. In Non traditional feed sources for use in swine production (ed. P. A. Thacker, and R. N. Kirkwood). Butterworths, Stoneham, MA. 1990.

23. Jørgensen H, Serena A, Hedemann MS, Bach Knudsen KE. The fermentative capacity of growing pigs and adult sows fed diets with contrasting type and level of dietary fibre. Livest Sci. 2007;109:111-4.

24. González-Alvarado JM, Jiménez-Moreno E, Valencia DG, Lázaro R, Mateos GG. Effects of fiber source and heat processing of the cereal on the development and $\mathrm{pH}$ of the gastrointestinal tract of broilers fed diets based on corn or rice. Poult Sci. 2008;87:1779-95.

25. Berrocoso JD. Effects of fiber inclusion on growth performance and nutrient digestibility of piglets reared under optimal or poor hygienic conditions. J Anim Sci. 2015;93:3919-31.

26. Montagne L, Pluske JR, Hampson DJ. A review of interactions between dietary fibre and the intestinal mucosa, and their consequences on digestive health in young non-ruminant animals. Anim Feed Sci Technol. 2003;108:95-117.

27. Soyka WJ, Lloyd MK, Sweney EJ. Escherichia coli serotypes associated with certain pig diseases. Res Vet Sci. 1960;1:17-27.

28. McDonald DE, Pethick DW, Mullan BP, Hampson DJ. Increasing viscosity of the intestinal contents alters small intestinal structure and intestinal growth, and stimulate proliferation of enterotoxigenic Escherichia coli in newlyweaned pigs. Br J Nutr. 2001;86:487-98.

29. Hopwood DE, Pethick DW, Hampson DJ. Increasing the viscosity of the intestinal contents stimulates proliferation of enterotoxigenic Escherichia coli and Brachyspira pilosicoli in weaner pigs. Br J Nutr. 2002;88:523-32.

30. Proházska L. Antibacterial mechanism of volatile fatty acids in the intestinal tract of pigs against Escherichia coli. J Vet Med. 1986;33:166-73.

31. May T, Mackie RI, Fahey GC, Cremin JC, Garleb KA. Effect of fiber source on short-chain fatty acid production and on the growth and toxin production by Clostridium Difficile. Scand J Gastroenterol. 1994;29:916-22.

32. Edwards SA. A new look on the role of fibre in the diet of pigs. Proceedings of the 6th European Society of Veterinary Internal Medicine. 1996; 90-91.

33. Williams BA, Verstegen MWA, Tamminga S. Fermentation in the large intestine of single-stomached animals and its relationship to animal health. Nutr Res Rev. 2001;14:207-27.

34. Bindelle J, Buldgen A, Delacollette M, Wavreille J, Agneessens R, Destain $J P$, et al. Influence of source and concentrations of dietary fiber on in vivo nitrogen excretion pathways in pigs as reflected by in vitro fermentation and nitrogen incorporation by fecal bacteria. J Anim Sci. 2009;87:583-93.

35. Freire JPB, Guerreiro AJG, Cunha LF, Aumaitre A. Effect of dietary fibre source on total tract digestibility, caecum volatile fatty acids and digestive transit time in the weaned piglet. Anim Feed Sci Technol. 2000;87:71-83.

36. Chabeauti E, Noblet J, Carré B. Digestion of plant cell walls from four different sources in growing pigs. Anim Feed Sci Technol. 1991;32: 207-13.

37. Varel VH, Fryda SJ, Robinson IM. Cellulolytic bacteria from pig large intestine. Appl Environ Microbiol. 1984;47:219-21.

38. Eggum BO. Blood urea measurement as a technique for assessing protein quality. Br J Nutr. 1970;24:983-8.

39. Hahn JD, Biehl RR, Baker DH. Ideal digestible lysine for early and late finishing swine. J Anim Sci. 1995;73:773-84.

40. Yakar S, Rosen CJ, Beamer WG, Ackert-Bicknell CL, Wu Y, Liu JL, et al. Circulating levels of IGF-1 directly regulate bone growth and density. I Clin Invest. 2002;110:771-81.

41. Bhutta ZA, Bang P, Karlsson E, Hagenas L, Nizami SQ, Sorder O. Insulin-like growth factor I response during nutritional rehabilitation of persistent diarrhea. Arch Dis Child. 1999:80:438-42.
42. Savage DC. Gastrointestinal microflora in mammalian nutrition. Annu Rev Nutr. 1986;6:155-78.

43. Liebler EM, Pohlenz JF, Whipp SC. Digestive system. In: Leman AD, Straw BE, Mengeling WL, D'Allaire S, Taylor DJ, editors. Diseases of swine. lowa: lowa State University Press; 1992. p. 12-20.

44. Weber TE, Kerr BJ. Butyrate differentially regulates cytokines and proliferation in porcine peripheral blood mononuclear cells. Vet Immunol Immunopathol. 2006;113:139-47.

\section{Submit your next manuscript to BioMed Central and we will help you at every step:}

- We accept pre-submission inquiries

- Our selector tool helps you to find the most relevant journal

- We provide round the clock customer support

- Convenient online submission

- Thorough peer review

- Inclusion in PubMed and all major indexing services

- Maximum visibility for your research

Submit your manuscript at www.biomedcentral.com/submit
Biomed Central 